\title{
Implementation of food and nutrition actions in the context of family health strategy, Paraíba, Brazil
}

\author{
Implantación de las acciones de alimentación y nutrición en la Estrategia Salud de \\ la Familia, Paraíba, Brasil \\ Implantação das ações de alimentação e nutrição na Estratégia Saúde da Família, \\ Paraíba, Brasil
}

Dixis Figueroa Pedraza ${ }^{1}$

1 PhD in Nutrition. Department of Nursing and Postgraduate Program in Public Health, State University of Paraíba, Campina Grande, Paraíba, Brazil

Recibido: 18/04/2018. Aprobado: 24/04/2019. Publicado: 01/10/2019

Figueroa-Pedraza D. Implementation of food and nutrition actions in the context of family health strategy, paraíba, brazil. Rev. Fac. Nal. Salud Pública. 2019;37(3):98-109. Dor:10.17533/udea.rfnsp.v37n3a11

\begin{abstract}
Objective: To evaluate the implementation of food and nutrition actions in child health care by family health teams in two municipalities of Paraíba, Brazil. Methodology: Evaluative survey of implementation analysis. Nine health teams in each municipality were randomly selected. Eighteen under-five children were selected, on average, from each team to represent this population group. The structure, the work process and the users' evaluation were analyzed. For the evaluation of the services from the perspective of the users, the child version of the PCATool questionnaire was used. Results: Scores of the work process and users' evaluation indicated a fragmented attention in both municipalities, although with
\end{abstract}

some differences between them. In the users' evaluation using the PCATool questionnaire, only the item completeness in the Municipality 1 reached the "advanced" level. Deficient promotion and prevention practices, growth monitoring and teamwork stood out with scores correlated with the users' evaluation, especially in the municipality with the best work process. Conclusion: There are impairments to completeness and quality associated with deficiencies in the implementation of food and nutrition actions directed at children's health.

---------Keywords: Primary Health Care, Health Planning, Nutrition Policy, Brasil. 


\section{Resumen}

Objetivo: Evaluar la implantación de las acciones de alimentación y nutrición en la atención a la salud del niño por equipos de salud de la familia en dos municipios de Paraíba, Brasil. Metodología: Investigación evaluativa de análisis de implantación. En cada municipio fueron seleccionados aleatoriamente, nueve equipos de salud que contribuyeron, cada uno, en media con 18 niños menores de cinco años representativos de ese grupo poblacional. Se analizó la estructura, el proceso de trabajo y la perspectiva de los usuarios. Fueron definidos puntajes para las tres dimensiones y sus sub-dimensiones. Para la evaluación de los servicios en la perspectiva del usuario, la versión de cuidado al niño del PCATool fue usada Resultados: Los puntajes del proceso de trabajo y de la evaluación de los usuarios indicaron atención fragmentada en los dos municipios, con diferencias entre ellos. Según la evaluación de los servicios por parte del usuario usando el PCATool, apenas la integralidad en el Municipio 1 obtuvo el nivel "avanzado". Se destacaron deficiencias en prácticas de promoción y prevención y en la vigilancia del crecimiento, resaltó el trabajo en equipo, cuyos puntajes estuvieron correlacionados con la perspectiva de los usuarios, más fuertemente en el municipio con mejor proceso de trabajo. Conclusiones: Fueron constatadas deficiencias en la implantación de las acciones de alimentación y nutrición, con limitaciones en la integralidad y calidad de los cuidados de salud de los niños menores de cinco años.

--------Palabras clave: Atención Primaria de Salud, Planificación en Salud, Política Nutricional, Brasil.

\section{Resumo}

Objetivos: Avaliar a implantação das ações de alimentação e nutrição na atenção à saúde da criança por equipes de saúde da família em dois municípios do estado da Paraíba, Brasil. Metodologia: Pesquisa avaliativa de análise da implantação. Em cada município foram selecionadas, aleatoriamente, nove equipes de saúde que contribuíram, cada uma, em média, com 18 crianças menores de cinco anos representativas desse grupo populacional. Analisou-se a estrutura, o processo de trabalho e a avaliação dos usuários. Foram definidos escores para as três dimensões e suas subdimensões. Para a avaliação dos serviços na perspectiva do usuário, a versão criança do PCATool foi usada. Resultados: Os escores do processo de trabalho e da avaliação dos usuários indicaram atenção fragmentada nos dois municípios, porém, com diferenças entre eles. $\mathrm{Na}$ avaliação do usuário dos serviços por meio do PCATool, apenas a integralidade no Município 1 obteve o nível "avançado". Destacaram-se deficiências em práticas de promoção e prevenção e na vigilância do crescimento, bem como no trabalho em equipe, cujos escores estiveram correlacionados com a avaliação dos usuários, mais fortemente no município com melhor processo de trabalho. Conclusões: Constataramse deficiências na implantação das ações de alimentação e nutrição, com prejuízos à integralidade e à qualidade dos cuidados de saúde das crianças menores de cinco anos.

--------Palavras-chave: Atenção Primária à Saúde, Planejamento em Saúde, Política Nutricional, Brasil.

\section{Introduction}

The Family Health Strategy (FHS) was established in Brazil as the main alternative for reorganization of Primary Health Care (PHC) and achievement of the objectives of universality, equity and integrality of the unified health system (SUS) [1-3]. For this, the FHS needs to combine technologies and forces favorable to change, with practices characterized by intersectoriality, permanent education, monitoring, evaluation and stimulation of popular participation [3].

The FHS has brought improvements in the universalization of access, coverage, targeting, hosting and bond among professionals. However, there are limitations in terms of territorialization, community participation and intersectoriality to address the social determinants of health and, especially, in terms of integrality of care [3]. In order that the FHS be able carry out its role of reorienting the health system, enormous challenges related to infrastructure, technological capacity, management professionalization, multiprofessional work and labor relations needs to be overcome [2].

The process of epidemiological transition of the Brazilian population has been characterized by the persistence of infectious diseases and malnutrition and their coexistence with chronic diseases [4]. Thus, Brazilian health services have been challenged to provide continuous and integrated responses to meet the needs of the country [2]. Food and nutrition, in this sense, represent a basic requirement for the promotion and protection of health [4]. Furthermore, the development of food and nutrition actions in a qualified and multidisciplinary manner is essential for compliance with the principles of integrality, universality and resolubility of health care in the context of PHC [5].

Despite this, the implementation of food and nutrition actions in the PHC is still incipient [6,7]. A recent review focusing on growth monitoring found that there are strong obstacles in both the structure and work 
process that hamper the development of these basic actions [8]. At the same time, few studies have been carried out in the FHS to evaluate food and nutrition actions [9]. The present study aimed to evaluate the implementation of food and nutrition actions in child health care by family health teams in two municipalities of Paraíba, Brazil.

\section{Methodology}

This is an evaluative survey that used the type 2 analysis design of implementation. A variation in the degree of implementation and its relation with the quality of the attention (effects) was observed [10].

The study was conducted in the context of FHS in two municipalities in the state of Paraíba selected for convenience. The choice of municipalities considered similarities of geographic position (location in the metropolitan area of the state capital with access to the available network of services), degree of urbanization (almost 100\%), demographic-social indicators (average human development index - 0.748 in Municipality 1 and 0.649 in Municipality 2) and traditional organization of primary health services $(100 \%$ of the population covered by the FHS). Municipality 1 has a population of 57,944 inhabitants, of which 4,596 (7.9\%) are under-five children, and it has a health system composed of 19 FHS teams. Municipality 2 has a population of 99,716 inhabitants, of which 7,862 (7.9\%) are under-five children, and has a health system composed of 28 FHS teams. The two municipalities differ in the composition of the health teams: nutritionist are included in the development of food and nutrition actions in the FHS teams since 2001 in the Municipality 1, while in the Municipality 2, nutritionists work exclusively in Family Health Support Centers (FHSC), assisting physicians and nurses of health teams in the development of food and nutrition actions. Municipality 1 also presents a better situation in relation to health professionals working at SUS and PHC.

The population of the study was represented by children less than five years of age. Parameters resulting from the evaluation of the quality of health care provided to children in the FHS were used for sample size calculation, according to the view of users in the municipality of Montes Claros, Minas Gerais [11]. In this study, the negative evaluation of quality service in the teams formed by doctors and nurses with residency in Family Health reached a rate of $41.9 \%$, and of teams composed by professionals without this specific training, $58.1 \%$. Thus, considering the expected prevalence of negative evaluation of health services by users of $41.9 \%$, in Municipality 1 (with nutritionists in the family health team), and $58.1 \%$ in Municipality 2, and considering $95 \%$ of level of confidence, $80 \%$ of power, $10 \%$ of increase to compensate for possible losses, and a design effect of 1.2 , there was a need to observe 157 children per municipality.

The sample was selected in two stages. In the first, the family health teams were randomly drawn; in the second stage, a fixed number of children was intentionally selected. Nine FHS teams were selected in each municipality. This corresponded to about half of the teams of Municipality 1 and 1/3 of those of Municipality 2. Each team contributed, on average, with 18 children to the total sample that met two criteria: i. intentional sampling among all childcare consultations performed on the day of data collection on a typical work day; ii. a number of children necessary to complete 18 participants, based on the number intentionally sampled, was selected from those children sent to the health services by Community Health Agents (CHA), according to work routine. All professionals in charge of childcare consultations and 1/3 of the CHA in activity in the teams drawn in both municipalities were included.

Data collection was carried out in health facilities between July and December 2014. The team was composed by health professionals and students with previous experience in field work and supervised by a trained professional. The quality control of the study included training and standardization of the interviewers, construction of an Instruction Manual and a pilot study in a third municipality in Paraíba that was not part of the sample.

The implementation of actions directed to children's health, with emphasis on food and nutrition, was based on structure and process dimensions. The quality of attention was based on the users' evaluation considered the assistance in large form, and not with emphasis in food and nutrition actions.

Information on the structure of health units was obtained using a standardized questionnaire with closed questions. The questionnaire was answered by the health team with nurses in the leadership.

The information about the work process was obtained considering three actors: the professional that carried out the childcare consultation (which was the nurse practically in all the teams), the CHA and the health team. In the case of the professional in charge of childcare consultations, the actions were defined based on the programmatic agenda of attention in the FHS regarding food and nutrition actions [5] as well as actions specifically concerned with growth monitoring [12], as recommended by the Ministry of Health. The first ones were obtained using a standardized questionnaire with closed questions. Information on growth monitoring was obtained from the observation of childcare consultations, taking notes in a specific form with "yes" and "no" answers. 
In the case of the CHA, actions were defined based on the integrality of services rendered according to the Primary Care Assessment Instrument (PCATool) [13]. The categories with alternatives "certainly yes" and "probably yes" were grouped and considered as positive responses, while the alternatives "certainly not" and "probably not" were grouped and considered as negative responses.

The performance of the health team in food and nutrition actions was analyzed considering the adequacy of use (version in hands) and completion (records related to the nutritional status of the child) of the Child Health Handbook (CHH) [14]. The possession of the third version of the $\mathrm{CHH}$ was considered appropriate. To decide on the adequacy of completion of the $\mathrm{CHH}$, all parameters were analyzed considering the age of the child at the time of the survey. The graphs of cephalic perimeter by age, weight by age, height by age and Body Mass Index by age were judged for adequacy based on the number of records consonant with the minimum number of consultations recommended by the Ministry of Health [12]; the notes on preventive supplementation of iron and vitamin A were judged based on the number of records of iron supplement bottles delivered consonant with the recommendation of the National Iron Supplementation Program [15]; the notes on preventive iron and vitamin A supplementation and/or the recordings of vaccines were judged based on the number of records of vitamin A supplementation as recommended by the National Vitamin A Supplementation Program [16]; and the notes on the vaccines were judged based on the records in consonance with the recommendation of the National Immunization Program [17].
For the evaluation of the services from the perspective of the users, the child version of the PCATool questionnaire was used [13], including the components first contact access - use, first contact access - accessibility, longitudinality and completeness - services provided, which was applied to the mothers of children. Because the questions C2, C4, C5 and D10 were elaborated in an inverse manner (the higher the value, the lower the orientation for the PHC), they had their values reversed $(4=1,3=2,2=3,1=4)$, following the instrument specifications. For the purposes of the present study, the categories with alternatives "certainly yes" and "probably yes" were grouped and considered as positive responses, while the categories with alternatives "certainly not" and "probably not" were grouped and considered as negative responses.

Table 1 shows for each dimension of study, the subdimensions, the items of analysis and the values assigned in the evaluation of each one of these dimensions. Data were examined through a scoring system in which the sub-dimensions and dimensions were derived from the sum of the scores of their components. The degree of implementation was determined by the sum of the scores of the structure and of the process divided by two (total number of dimensions, each with the same weight). All scores were categorized into three levels considering their value in relation to the maximum possible score: "incipient" (0.0 to $33.3 \%)$, "intermediate" (33.4 to 66.7\%) and "advanced" (66.8 to $100.0 \%$ ). The incipient scenario was understood as a proposal of "simplified attention"; the intermediate scenario as "fragmented attention"; and the advanced scenario as "comprehensive attention".

Table 1. Variables of the dimensions, process and users' evaluation with respective scores of the actions directed to children's health with emphasis on food and nutrition in the Family Health Strategy of two municipalities of the State of Paraíba, 2014.

\begin{tabular}{|c|c|}
\hline & Variable (score) \\
\hline \multicolumn{2}{|c|}{ Degree of implementation [10.0: $(1+2) / 2]$} \\
\hline \multicolumn{2}{|c|}{ 1.- Structure dimension $(10.0: 1.1+1.2+1.3+1.4+1.5+1.6+1.7)$} \\
\hline 1.1.- Human resources (1.0: each item $=0.25)$ : & $\begin{array}{l}\text { Minimum team completeness, support from the FHSC to the team, physi- } \\
\text { cian and/or nurse with stable bond and a minimum of two years working as } \\
\text { part of the team, availability of nutritionist (in the team }=0.25 \text {; support to } \\
\text { the team by a FHSC professional }=0.125 \text { ). }\end{array}$ \\
\hline $\begin{array}{l}\text { 1.2.- Technical training of human resources in } \\
\text { relation to food and nutrition actions (1.0: each } \\
\text { item }=0.2) \text { : }\end{array}$ & $\begin{array}{l}\text { Development/coordination of main food and nutrition activities (by nutrition- } \\
\text { ist }=0.2 \text {, by doctor or nurse }=0.1 \text { ), doctor and/or nurse with postgraduate } \\
\text { degree in public health/family health/maternal and child health/nutrition, } \\
\text { doctor and/or nurse with specific training to work with PHC/FHS, doctor } \\
\text { and/or nurse with specific training to work with children's health (PAISC, } \\
\text { AIDPI, vaccination room), doctor and/or nurse with training in the National } \\
\text { Policy for Food and Nutrition or in the organization of food and nutrition } \\
\text { actions in PHC/FHS. }\end{array}$ \\
\hline
\end{tabular}




\section{Variable (score)}

1.3.- Organization of services (1.0: each item $=$ $0.2)$ :

1.4. Availability of vaccines (2.0: each item $=$ $0.2)$ :

1.5.- Availability of drugs and supplements (2.0: each item $=0.2$ ) (available: presence of at least one product for each specified subgroup):

1.6.- Availability of equipment and supplies (1.5: each item $=0.1$ ):

1.7.- Availability of protocols/guidelines/norms related to child health care and development of food and nutrition actions (1.5: each item $=$ $0.1)$ :
Defined geographical area, up-to-date manuals of the Ministry of Health for childcare, SIAB management (collection, analysis), periodic meetings of the health team, reference system (transport and form for referral $=0.2$, transport or form for referral $=0.1$, neither transport nor form for referral $=0.0$ ).

Anti-measles, BCG (antituberculosis), DPT (antidiphtheria, tetanus and whooping cough), DT (antidiphtheria and juvenile tetanus type), HEP B (anti-hepatitis B), HIB (anti-hemophilic influenza), VOP (oral anti-polio), VORH (Human Rotavirus oral vaccine), SRC (triple viral), Tetravalent (DTP+Hib).

Adrenaline, oral antibiotic (suspension), anticonvulsant, antihelmintic (suspension), antipyretic (suspension), bronchodilator, topical medication (nystatin, potassium permanganate), oral rehydration salts, ferrous sulfate vitamin $\mathrm{A}$

Children measuring equipment, children weighing scale, adult measuring equipment, adult weighing scale, Child Health Handbook, medical record form, vaccine refrigerator, vaccine thermometer, vaccum thermometer, nebulizer, disposable syringes and needles, glucometer, clinical thermometer, otoscope, stethoscope.

Prenatal care, vaccination coverage, care to healthy newborns, growth monitoring, breastfeeding, care to undernourished children, diarrheal disease control, care to acute respiratory infection, food and nutrition actions matrix in PHC, SISVAN protocols, FHSC guidelines, food guidelines for the Brazilian population, food guidelines for under-two children, operational materials of micronutrient supplementation programs, conditions of the Bolsa Família Program.

\section{2.- Process dimension (10.0: $2.1+2.2+2.3)$}

Identification of unhealthy lifestyles related to the development of overweight/obesity, evaluation of breastfeeding practices and/or food consumption, height assessment to identify problems in linear growth, weight assessment to identify problems in ponderal growth, identification of signs of malnutrition, identification of signs of infectious and parasitic diseases, criteria adopted for reference in cases of acute diarrheal disease (adoption of at least three signs: dehydration, lethargy, unconsciousness, restlessness, irritation, deep eyes, fold sign, child's inability to suck or drink liquids, bulging of the fontanelle), criteria adopted for reference in cases of acute respiratory infection (adoption of at least three signs: severe subcostal delivery or high RF in children under two months of age, subcostal delivery in children between two months and fiver years of age, abnormal somnolence, stridor, severe wheezing, cough for 30 days or more), referral in cases of malnutrition (referral to nutritionist for nutritional evaluation and dietary therapy)

Guidelines related to the development of infectious and parasitic diseases, encouragement/support and protection of breastfeeding and complementary feeding, food orientation linked to iron and vitamin A supplementation, food orientation directed to families benefiting from the Bolsa Familia Program, promotion of healthy eating based on food guides for the Brazilian population and for under-two children, development of activities under the Program to Combat Nutritional Deficiencies (preventive supplementation with iron and vitamin A), monitoring of conditions of the Bolsa Família Program, prevention of cases of acute diarrheal disease (adoption of at least one of the important measures to prevent acute diarrheal disease: guidance indicating maintenance of normal feeding of the child, guidelines on care in cases of dehydration, guidelines on the use of homemade liquids and oral rehydration), prevention of cases of acute respiratory infection (guidelines on the average duration of acute respiratory infections), prevention of cases of malnutrition (adoption of at least three important actions to prevent malnutrition: guidance on breastfeeding, guidelines on healthy eating, guidelines on food and personal hygiene, guidelines on immunization, guidelines on growth and development, guidelines on returning to the service to monitor height and weight). 


\section{Variable (score)}

2.1.3- Food and Nutrition Surveillance (0.75: each item $=0.25$ ):

2.1.4- Monitoring of the growth of under-five children in childcare consultations (2.0: each item $=0.10$; scoring for each variable $=$ sum of the scores of each child analyzed in the team's area of coverage/total number of children living in the team's area of coverage):
Monitoring/surveillance of growth in childcare consultations, completion of the $\mathrm{CHH}$ with records of growth in the corresponding charts (cephalic perimeter, weight, height), micronutrient supplementation, implementation of SISVAN activities (feeding the system, sending information to municipal authorities, data analysis)

Measurement of weight, measurement of height, measurement of cephalic perimeter, record of weight in the chart, record of height in the chart, record of the cephalic perimeter in the chart, inquire about the $\mathrm{CHH}$ in hands, $\mathrm{CHH}$ possession, record of weight in the $\mathrm{CHH}$ chart, record of height in the $\mathrm{CHH}$ chart, record of cephalic perimeter in the $\mathrm{CHH}$ chart, guidance to mothers on the growth of the child, identification and guidance to the mothers on the nutritional status of the child according to the position of the weight in the weight $X$ age graph, identification and guidance to the mothers on the nutritional state of the child according to the position of height in the height $X$ age graph, identification and guidance to the mothers on the nutritional status of the child according to the position of the cephalic perimeter in the cephalic perimeter $X$ age graph, guidance to mothers on the importance of growth monitoring, guidance to mothers on the importance of childcare consultations.

2.2.- Performance of community health agents (1.0: each item $=0.2$, scoring of each variable $=$ sum of the scores of the interviewed community health agents/ total number of interviewed community health agents):

2.3.- Performance of health teams with a focus on health and growth surveillance according to records in the Child Health Handbook (4.0: each item $=0.50$; scoring of each variable $=$ sum of the scores of each child analyzed from the area covered by the team/total number of children analyzed from the area covered by the team):
Guidance to parents on home safety, guidance to parents on keeping children safe, guidance to parents on how to deal with children's behavioral problems, guidance to parents on ways to keep children healthy, guidance to parents on changes in growth and development expected for each age group.

Cephalic perimeter per age, weight per age, height per age, BMl per age, iron supplementation, vitamin A supplementation, vaccination, $\mathrm{CHH}$ version in hands.

\section{3.- User's evaluation dimension $(10.0: 3.1+3.2+3.3+3.4)$}

3.1.- First contact access - use (1.5: each item $=0.5$; scoring of each variable $=$ sum of the scores of each child analyzed from the area covered by the team/total number of children analyzed from the area covered by the team):

3.1.- First contact access - accessibility (1.5: each item $=0.5$; scoring of each variable $=$ sum of the scores of each child analyzed from the area covered by the team/total number of children analyzed from the area covered by the team):

3.3.- Longitudinality (3.5: each item $=0.25$, scoring of each variable $=$ sum of the scores of each child analyzed from the area covered by the team/total number of children analyzed from the area covered by the team):

3.4.- Completeness - services provided (2.0: each item $=0.4$, scoring of each variable $=$ sum of the scores of each child analyzed from the area covered by the team/total number of children analyzed from the area covered by the team):
Use for follow-up consultation, use for new health problem, referral to specialist.

Provision of care in the same day of search, time spent for scheduling consultations, time waiting for consultation, consultation for immediate need, telephone counseling.

Rotativity, possibility of telephone communication, understanding of the user by the doctor/nurse, understanding of the doctor/nurse by the user, availability of time to talk, confidence, knowledge of the child (as a person and not only as a patient), knowledge of medicines the child takes, desire to change to another service or profession, knowledge of the child as a patient, knowledge of the most important problems of the family, knowledge about the work or employment situation of the family members, knowledge about possible problems to obtain or pay for medicines needed by the child.

Guidance to parents on home safety, guidance to parents on keeping children safe, guidance to parents on how to deal with children's behavioral problems, guidance to parents on ways to keep children healthy, guidance to parents on changes in growth and development expected for each age group. 
The data collected were typed in double entry. The Validate application of the Epi Info Software v. 3.3.2 was used to analyze the consistency of the data. Continuous variables with normal distribution were expressed as mean \pm standard deviation, with asymmetric distributions presented as median and interquartile intervals $\left[\mathrm{IQ}_{25-75}\right]$. The municipalities were compared using the parametric t-test for samples expressed as means, or the nonparametric Mann-Whitney test for samples expressed as medians. The correlation between the users' evaluation scores and their respective sub-dimensions with the scores related to the structure and work process, revealing the trend (increasing, decreasing or inverse) between the two variables, was analyzed using the Pearson correlation coefficient (if data had normal distribution) or the Kendall correlation coefficient (if data had asymmetric distribution). The accepted level of significance was $5 \%$ in all statistical analyses. Data normality was assessed using the Kolmogorov-Smirnov test. The Software Stata v.12.0 was used.

This study was approved by the Research Ethics Committee oftheStateUniversityofParaíbain 17/12/2013 under protocol number 19689613.3.0000.5187. All participants signed the Informed Consent Term as condition to participate in the study. All participants signed the Free and Informed Consent Term as a prerequisite to participate in the research and were guaranteed the freedom of participation, privacy and confidentiality of the information.

\section{Results}

The sample consisted of 321 under-five children; 153 lived in Municipality 1 and 168 in Municipality 2. A

Table 2. Mean or median scores related to the structure of the health units, the work process and the users' evaluation of the actions directed to children's health, with emphasis on food and nutrition, in the Family Health Strategy of two municipalities of the State of Paraíba, 2014.

\begin{tabular}{|c|c|c|c|}
\hline \multirow[t]{2}{*}{ Sub-dimension/Dimension (Maximum score) } & \multicolumn{2}{|c|}{$\begin{array}{c}\text { Mean or median } \text { scores }^{*} \text { and their classifi- } \\
\text { cation }^{+}\end{array}$} & \multirow[t]{2}{*}{$p^{\S}$} \\
\hline & Municipality 1 & Municipality 2 & \\
\hline Structure (10.0) & $\begin{array}{l}7.572 \pm 0.820 \\
\text { Advanced }\end{array}$ & $\begin{array}{l}6.731 \pm 0.582 \\
\text { Advanced }\end{array}$ & 0.023 \\
\hline Human resources (1.0) & $\begin{array}{l}0.861 \pm 0.132 \\
\text { Advanced }\end{array}$ & $\begin{array}{l}0.597 \pm 0.195 \\
\text { Intermmediate }\end{array}$ & 0.004 \\
\hline Technical training of human resources in food and nutrition (1.0) & $\begin{array}{l}0.855 \pm 0.207 \\
\text { Advanced }\end{array}$ & $\begin{array}{l}0.656 \pm 0.151 \\
\text { Intermmediate }\end{array}$ & 0.032 \\
\hline Organization of services (1.0) & $\begin{array}{l}0.633 \pm 0.239 \\
\text { Intermmediate }\end{array}$ & $\begin{array}{l}0.678 \pm 0.273 \\
\text { Advanced }\end{array}$ & 0.718 \\
\hline Availability of vaccines (2.0) & $\begin{array}{l}1.800[1.500-1.800] \\
\text { Advanced }\end{array}$ & $\begin{array}{l}1.800[1.600-1.800] \\
\text { Advanced }\end{array}$ & 1.000 \\
\hline Availability of drugs and supplements (2.0) & $\begin{array}{l}1.600[1.400-1.600] \\
\text { Advanced }\end{array}$ & $\begin{array}{l}1.400[1.300-1.400] \\
\text { Advanced }\end{array}$ & 0.131 \\
\hline Availability of equipment and supplies (1.5) & $\begin{array}{l}1.500[1.400-1.500] \\
\text { Advanced }\end{array}$ & $\begin{array}{l}1.300[1.250-1.450] \\
\text { Advanced }\end{array}$ & 0.153 \\
\hline Availability of protocols (1.5) & $\begin{array}{l}0.567 \pm 0.439 \\
\text { Intermmediate }\end{array}$ & $\begin{array}{l}0.355 \pm 0.336 \\
\text { Incipiente }\end{array}$ & 0.269 \\
\hline Work process (10.0) & $\begin{array}{l}5.913 \pm 0.406 \\
\text { Intermmediate }\end{array}$ & $\begin{array}{l}4.864 \pm 0.629 \\
\text { Intermmediate }\end{array}$ & 0.001 \\
\hline Performance of the professional in nutritional diagnosis (1.0) & $\begin{array}{l}0.722 \pm 0.007 \\
\text { Advanced }\end{array}$ & $\begin{array}{l}0.744 \pm 0.005 \\
\text { Advanced }\end{array}$ & 0.555 \\
\hline $\begin{array}{l}\text { Performance of the professional in health promotion and disease } \\
\text { prevention (1.25) }\end{array}$ & $\begin{array}{l}0.653 \pm 0.034 \\
\text { Intermmediate }\end{array}$ & $\begin{array}{l}0.555 \pm 0.036 \\
\text { Intermmediate }\end{array}$ & 0.286 \\
\hline Performance of the professional in food surveillance $(0.75)$ & $\begin{array}{l}0.589 \pm 0.007 \\
\text { Advanced }\end{array}$ & $\begin{array}{l}0.639 \pm 0.170 \\
\text { Advanced }\end{array}$ & 0.052 \\
\hline $\begin{array}{l}\text { Performance of the professional in growth monitoring } \\
\text { (observation of childcare consultations) (2.0) }\end{array}$ & $\begin{array}{l}1.165 \pm 0.024 \\
\text { Intermmediate }\end{array}$ & $\begin{array}{l}0.883 \pm 0.156 \\
\text { Intermmediate }\end{array}$ & 0.073 \\
\hline
\end{tabular}




\begin{tabular}{|c|c|c|c|}
\hline \multirow{2}{*}{ Sub-dimension/Dimension (Maximum score) } & \multicolumn{2}{|c|}{$\begin{array}{l}\text { Mean or median } \text { scores }^{\star} \text { and their classifi- } \\
\text { cation }^{+}\end{array}$} & \multirow[t]{2}{*}{$p^{\S}$} \\
\hline & Municipality 1 & Municipality 2 & \\
\hline Performance of the community health agent (1.0) & $\begin{array}{l}0.837 \pm 0.013 \\
\text { Advanced }\end{array}$ & $\begin{array}{l}0.957 \pm 0.001 \\
\text { Advanced }\end{array}$ & 0.053 \\
\hline $\begin{array}{l}\text { Performance of the health team (completion of the Child Health } \\
\text { Handbook) (4.0) }\end{array}$ & $\begin{array}{l}2.035 \pm 0.323 \\
\text { Intermmediate }\end{array}$ & $\begin{array}{l}1.085 \pm 0.269 \\
\text { Incipiente }\end{array}$ & 0.000 \\
\hline Degree of Implementation (10.0) & $\begin{array}{l}6.743 \pm 0.517 \\
\text { Advanced }\end{array}$ & $\begin{array}{l}5.798 \pm 0.594 \\
\text { Intermmediate }\end{array}$ & 0.004 \\
\hline Users' Evaluation (10.0) & $\begin{array}{l}6.048 \pm 0.337 \\
\text { Intermmediate }\end{array}$ & $\begin{array}{l}4.754 \pm 1.122 \\
\text { Intermmediate }\end{array}$ & 0.007 \\
\hline Use (1.5) & $\begin{array}{l}1.137 \pm 0.029 \\
\text { Advanced }\end{array}$ & $\begin{array}{l}0.985 \pm 0.045 \\
\text { Intermmediate }\end{array}$ & 0.116 \\
\hline Accessibility (3.0) & $\begin{array}{l}1.382 \pm 0.033 \\
\text { Intermmediate }\end{array}$ & $\begin{array}{l}1.149 \pm 0.129 \\
\text { Intermmediate }\end{array}$ & 0.102 \\
\hline Longitudinality (3.5) & $\begin{array}{l}2.173 \pm 0.071 \\
\text { Intermmediate }\end{array}$ & $\begin{array}{l}1.684 \pm 0.128 \\
\text { Intermmediate }\end{array}$ & 0.005 \\
\hline Integrality (2.0) & $\begin{array}{l}1.356 \pm 0.067 \\
\text { Advanced }\end{array}$ & $\begin{array}{l}0.935 \pm 0.086 \\
\text { Intermmediate }\end{array}$ & 0.005 \\
\hline
\end{tabular}

total of 119 children were enrolled in the study during childcare consultations (53 from Municipality 1 and 66 from Municipality 2). The sample of professionals was composed of 18 nurses (one per team) and 98 CHA (44 from Municipality 1 and 54 from Municipality 2).

Table 2 shows the results of the scores related to the structure of health units, work process and users' evaluation. The Municipality 2 presented an incipient classification for availability of protocols and health team performance, while all criteria were above this classification in Municipality 1. As for structure, the items with the best evaluation, classified as "advanced", in both municipalities, were availability of vaccines, equipment and medications/supplements. A similar result was found in the work process for the parameters of performance of professionals in food surveillance and in nutritional diagnosis and performance of the CHA. In the users' evaluation, only the item completeness in the Municipality 1 reached the "advanced" level. The

Table 3. Correlation between the scores of the users' evaluation and those of the structure of the health units and the work process of the degree of implementation of actions directed to children's health with emphasis on food and nutrition in the Family Health Strategy of two municipalities of the State of Paraíba, 2014.

\begin{tabular}{|c|c|c|c|c|c|c|}
\hline \multirow{3}{*}{ Sub-dimension/Dimension } & \multicolumn{6}{|c|}{ Users' evaluation } \\
\hline & \multicolumn{2}{|c|}{ Total } & \multicolumn{2}{|c|}{ Municipality 1} & \multicolumn{2}{|c|}{ Municipality 2} \\
\hline & $r$ & $p$ & $r$ & $p$ & $r$ & $p$ \\
\hline Structure & 0.384 & 0.0000 & 0.374 & 0.0000 & 0.313 & 0.0460 \\
\hline Human Resources & 0.699 & 0.0000 & 0.793 & 0.0000 & 0.572 & 0.0000 \\
\hline $\begin{array}{l}\text { Technical training of human resources in food } \\
\text { and nutrition (1.0) }\end{array}$ & 0.299 & 0.0000 & 0.273 & 0.006 & 0.254 & 0.0090 \\
\hline Organization of services & 0.303 & 0.0003 & 0.296 & 0.0002 & 0.381 & 0.0000 \\
\hline Availability of vaccines & 0.169 & 0.1603 & 0.106 & 0.1705 & 0.074 & 0.3657 \\
\hline Availability of drugs and supplements & 0.094 & 0.0953 & 0.096 & 0.0515 & 0.091 & 0.1015 \\
\hline Availability of equipment and supplies & 0.628 & 0.0000 & 0.621 & 0.0000 & 0.550 & 0.0176 \\
\hline Availability of protocols & 0.246 & 0.0000 & 0.298 & 0.0226 & 0.218 & 0.0293 \\
\hline Work process & 0.575 & 0.0000 & 0.625 & 0.0000 & 0.487 & 0.0002 \\
\hline
\end{tabular}




\begin{tabular}{|c|c|c|c|c|c|c|}
\hline \multirow{3}{*}{ Sub-dimension/Dimension } & \multicolumn{6}{|c|}{ Users' evaluation } \\
\hline & \multicolumn{2}{|c|}{ Total } & \multicolumn{2}{|c|}{ Municipality 1} & \multicolumn{2}{|c|}{ Municipality 2} \\
\hline & $r$ & $p$ & $r$ & $\mathrm{p}$ & $r$ & $p$ \\
\hline $\begin{array}{l}\text { Performance of the professional in nutritional } \\
\text { diagnosis }\end{array}$ & 0.346 & 0.0640 & 0.441 & 0.0542 & 0.262 & 0.0452 \\
\hline $\begin{array}{l}\text { Performance of the professional in health } \\
\text { promotion and disease prevention }\end{array}$ & 0.613 & 0.0000 & 0.727 & 0.0000 & 0.497 & 0.0000 \\
\hline $\begin{array}{l}\text { Performance of the professional in food } \\
\text { surveillance }\end{array}$ & 0.371 & 0.0872 & 0.382 & 0.0680 & 0.308 & 0.1860 \\
\hline $\begin{array}{l}\text { Performance of the professional in growth } \\
\text { monitoring (observation of childcare } \\
\text { consultations) }\end{array}$ & 0.698 & 0.0000 & 0.735 & 0.0000 & 0.688 & 0.0199 \\
\hline Performance of the community health agent & 0.415 & 0.1530 & 0.409 & 0.1147 & 0.429 & 0.1459 \\
\hline $\begin{array}{l}\text { Performance of the health team (completion of } \\
\text { the Child Health Handbook) }\end{array}$ & 0.729 & 0.0000 & 0.739 & 0.0000 & 0.704 & 0.0069 \\
\hline
\end{tabular}

r: Pearson (Normal distribution) or Kendall (Asymmetrical distribution) correlation coefficient; $\mathrm{p}$ : level of significance.

classification of the dimensions in both municipalities was identical: "advanced" for the structure and "intermediate" for the work process and for the users' evaluation. The classification of the degree of implementation was "advanced" in the Municipality 1 and "intermediate" in the Municipality 2.

Regarding differences in scores, it was observed that the criteria related to human resources had a better concept in Municipality 1. In the process, the Municipality 1 had a better concept in the performance of the health team. The users' evaluation of the Municipality 1 reached higher scores for longitudinality and completeness. The scores of the three dimensions and of the degree of implementation were different in the two municipalities, but higher in the Municipality 1.

The structure and work process dimensions showed significant correlations with the users' evaluation. In the process, which had stronger correlation than the structure, the performance of the health team was the sub-dimension with higher correlation coefficient. In the structure, 'human resources' was the criterion that presented the highest correlation. Stronger correlations were observed in Municipality 1 (Table 3).

\section{Discussion}

This is, to our knowledge, the first study evaluating the implementation of food and nutrition actions in the FHS and its relation with the evaluation of the health services by the user. Considering that the degree of implementation presented a better situation in the municipality whose FHS teams include nutritionists and higher score in the human resources sub-dimension (Municipality 1), it is plausible to suppose that the participation of these professionals can have a positive impact on the performance of the health teams when it comes to these actions.

Regarding the structure of the services, in both municipalities the scores presented "advanced" levels. However, there were differences between municipalities, with a better situation in Municipality 1, which is in line with reports in the literature that indicate differences in the structure of health units between municipalities in the country $[3,18]$. Considering that the most precarious structure in the Municipality 2 was conditioned to aspects related to human resources, the results of this study converge with those of a literature review that identified the lack of training of professionals as one of the main problems related to growth surveillance in the basic health network in Brazil [8].

Still regarding structure, it should be noted that the only item that presented an incipient degree was the availability of protocols. This problem is recurrent in studies on growth surveillance in the SUS primary care [8] and has been highlighted in a recent study [19]. This deficiency is a cause of concern, because numerous protocols are available [20]. It is necessary to investigate the reasons for this neglect.

The scoring of the performance of the professionals in charge of the childcare consultations regarding of health promotion, disease prevention and growth monitoring, as well as the work of the health team, as "intermediate" or "incipient", suggests a assistance practice not directed at promotion and prevention. Previous evaluations have found similar results $[19,21]$. On the other hand, it should be noted that despite the best evaluation of Municipality 1 in relation to the process, the higher scores in Municipality 2 in nutritional diagnosis and food surveillance, although not significant, reinforce the need for personnel training. 
The analysis of growth monitoring in childcare consultations presented an "intermediate" classification, which converges with that of the previous study that analyzed the criterion considering the completion of the $\mathrm{CHH}$ [22]. Although growth monitoring is recommended since the First International Conference on Primary Health Care and despite the fact that it represents a basic action to guarantee the integrality of health care in Brazil [23], research studies have shown that this practice is still incipient in primary child health care in the country $[8,24]$. This knowledge concerns both the results of studies whose analyses were mediated by the evaluation of the completion of the $\mathrm{CHH}$, regarding the results based on procedures, including not only records of body measurements, but also the adoption of guidelines based on the recorded data [8].

The problems in the use of the $\mathrm{CHH}$ have been discussed and systematized in the literature $[8,23]$. The deficiencies pointed out also include the aspects of food and nutrition contained in the instrument [23], what was also found in the present study. Infant growth is a dynamic process and the best method of follow-up is to perform the periodic record of weight, height and body mass index [23]. In Brazil, this process is feasible through the completion of $\mathrm{CHH}$ in PHC $[8,23]$. Thus, the use of the handbook reverts to meanings related to the quality of care offered to the children by the health teams [23]. In this sense, an objective poorly related with monitoring that indicates, at least, impairment of the capacity of care, that is, of the effectiveness, was observed in the results of this work, especially in the Municipality 2, which was classified as incipient.

Considering the analyses of the current study based on the mothers' professional orientations, the commitment of health promotion actions with growth monitoring practices is also evident. These results are similar to those confirmed in other surveys $[8,22]$. Therefore, gaps in care that neglect the complexity of growth and development, as well as the social determination of health are ratified [22].

The foregoing results on the work process of the health teams, besides obviously obstructing the opportunity to experience the whole process of growth and development, hinder the adherence and appreciation of the $\mathrm{CHH}$, the sharing of data among professionals and the dialogue between professionals and users. Thus, the non-implementation of growth monitoring may limit the chances of identifying risk situations, the longitudinality and the completeness of the assistance $[2,8,12]$.

According to the users' evaluation, the results of the present study show indicative scenarios of action of "fragmented" attention in the FHS, with Municipality 2 being in the worst situation, mainly in the longitudinality and completeness requirements. These findings are indicative of deficiencies in the structure and work process, with consequences in the regularity and continuity of care. Research studies in other localities have indicated better evaluations for longitudinality when compared to completeness [24,25], what was not observed in the current study that characterized the first criterion as intermediary in both municipalities. However, the results coincide with those of another reality in which longitudinality and accessibility were classified as insufficient [26].

Some studies have found that health professionals tend to make a more positive assessment of their actions than the users do [24,27]. This was confirmed in the present study when it was observed that the users' evaluation was not as positive as that of the professionals. Also there were the lower correlations with the users' evaluation in the scores based on the answers of the professionals in relation to those based on other sources of information (performance of the professionals in growth monitoring and performance of the health team), mainly in the Municipality 2. It is therefore accepted that this situation, besides being relevant in the evaluation of health services, is indicative of a possible information bias (more positive self-evaluation of professionals), although the planning and development of the research sought to avoid such situation.

The high correlation between structure and process with the users' evaluation indicates the importance of these issues in the quality of care. Thus, it is important to highlight the positive influences of human resources, organization of services, availability of equipment and inputs, monitoring of growth and performance of the health team on the users' evaluation verified in the current study, which is consistent with that reported by other authors [28-30]. The Portuguese experience has highlighted convergent results, reporting the importance of infrastructure conditions and teamwork in the performance and quality of the assistance [31]. The current study stresses the need to integrate food and nutrition actions in the list of health actions developed by family health teams in order to improve basic care and nutritional care offered to SUS users, according to the programmatic milestones of the area [5]. However, it should be emphasized that the results related to the evaluation of the users represent a broader aspect regarding the health care of the child, which, although it may be considered a proxy for the implementation of food and nutrition actions, is related not only to them.

The interpretation of the presented results must consider the convenience sample of two municipalities of the same State of the Federation. In any case, it is important to highlight the importance of this study based on the two cases studied. The complex sample design was not used in the analysis strategy, particularly by not treated of auto- powered sample. Regarding the correlation analysis, it should be emphasized that even 
when classified as strong and statistically significant, they only reveal the increasing, decreasing or inverse trend between the dimensions of the structure and the process with the evaluation of the user. Also, it should be considered that socioeconomic and social tension conditions may have influenced the results, especially considering that Municipality 2 is more populous and have inferior human development index.

The above considerations show that the degree of implementation of FHS actions focused on children's health with emphasis on food and nutrition have insufficient human capital, both in relation to professional training and practices developed. These professionals work every day in environments where the shortage of inputs prevails, posing a great challenge related to awareness, motivation and skills.

The synthesis of the dimensions evaluated lead to an "intermediate" scenario in the work process and health care quality of under-five children, and a "fragmented" attention with advances related to the mothers' adhesion to the FHS proposal and major challenges related to the longitudinality and completeness of care. In this sense, important deficiencies are highlighted in health preventive and promotion practices, growth monitoring, teamwork, food and nutrition issues, which make it difficult to assimilate integrality to reorient the care model, and compromise the quality.

\section{Authors' contributions}

DFP contributed to the design, analysis, planning and interpretation of data; writing of the article and critical review of intellectual content; final approval of the version to be published.

\section{Acknowledgements}

To the National Council for Scientific and Technological Development and the Foundation for Research Support of the State of Paraíba, for funding the research and for concession of scholarships. To undergraduate and graduate students who participated in data collection.

\section{Sources of funding}

Avaliação das ações de alimentação e nutrição no marco da Estratégia Saúde da Família em municípios do estado da Paraíba. Conselho Nacional de Desenvolvimento Científico e Tecnológico (476520/2013-4) and Fundação de Apoio à Pesquisa do Estado da Paraíba (37/13).

\section{Conflict of interest}

The authors declare no conflicts of interest and no personal, scientific, commercial or financial relationship with persons or institutions that could compromise the results presented in the article.

\section{Declaration of responsibility}

The authors declare that the points of view expressed are the responsibility of the author and not of the institution in which he works or of the funding source.

\section{References}

1. Sumar N, Fausto MCR. Atenção Primária à Saúde: a construção de um conceito ampliado. J Manag Prim Health Care 2014;5(2):202-12.

2. Oliveira MAC, Pereira IC. Atributos essenciais da Atenção Primária e a Estratégia Saúde da Família. Rev Bras Enferm 2013;66(Esp.):158-64.

3. Silva LA, Casotti CA, Chaves SCL. A produção científica brasileira sobre a Estratégia Saúde da Família e a mudança no modelo de atenção. Cienc Saude Colet 2013;18(1):221-32.

4. Jaime PC, Santos LMP. Transição nutricional e a organização do cuidado em alimentação e nutrição na Atenção Básica em Saúde. Divulgação Saúde Debate 2014;51:72-85.

5. Brasil. Ministério da Saúde. Matriz de ações de alimentação e nutrição na atenção básica de saúde. Brasília: Ministério da Saúde; 2009. (Série A. Normas e Manuais Técnicos). Available from: http://bvsms.saude.gov.br/bvs/publicacoes/matriz_alimentacao_ nutricao.pdf

6. Geus LMM, Maciel CS, Burda ICA, Daros SJ, Batistel S, Martins TCA, et al. A importância na inserção do nutricionista na Estratégia Saúde da Família. Cienc Saude Colet 2011;16(Supl. 1):797-804.

7. Recine E, Vasconcellos AB. Políticas nacionais e o campo da Alimentação e Nutrição em Saúde Coletiva: cenário atual. Cienc Saude Colet 2011;16(1):73-9.

8. Figueroa Pedraza D. Growth surveillance in the context of the Primary Public Healthcare Service Network in Brazil: literature review. Rev Bras Saúde Matern Infant 2016;16(1):7-19.

9. Canella DS, Silva ACF, Jaime PC. Produção científica sobre nutrição no âmbito da Atenção Primária à Saúde no Brasil: uma revisão de literatura. Cienc Saude Colet 2013;18(2):297-308.

10. Champagne F, Broussele A, Hartz Z, Contandriopoulos AP, Denis JL. A análise de implantação. In: Broussele A, Champagne F, Contandriopoulos AP, Hartz ZMA, organizadores. Avaliação: conceitos e métodos. Rio de Janeiro: Editora Fiocruz; 2011. p. 217-38.

11. Leão CDA, Caldeira AP. Avaliação da associação entre qualificação de médicos e enfermeiros em atenção primária em saúde e qualidade da atenção. Cienc Saude Colet 2011;16(11):4415-23.

12. Brasil. Ministério da Saúde. Saúde da criança: crescimento e desenvolvimento. Brasília: Ministério da Saúde; 2012. (Cadernos de Atenção Básica, $\mathrm{n}^{\circ}$ 33). Available from: http://bvsms. saude.gov.br/bvs/publicacoes/saude_crianca_crescimento_ desenvolvimento.pdf 
13. Brasil. Ministério da Saúde. Manual do instrumento de avaliação da atenção primária à saúde: primary care assessment tool pcatool - Brasil. Brasília: Ministério da Saúde; 2010. Available from: http://bvsms.saude.gov.br/bvs/publicacoes/manual_avaliacao_ pcatool_brasil.pdf

14. Brasil. Ministério da Saúde. Caderneta de Saúde da Criança menino. 8 ed. Brasília: Ministério da Saúde; 2013. Available from: http://bvsms.saude.gov.br/bvs/publicacoes/caderneta saude_crianca_menino.pdf

15. Brasil. Ministério da Saúde. Programa Nacional de Suplementação de Ferro: manual de condutas. Brasília: Ministério da Saúde; 2013. Available from: http://bvsms.saude.gov.br/bvs/publicacoes/ manual_suplementacao_ferro_condutas_gerais.pdf

16. Brasil. Ministério da Saúde. Manual de condutas gerais do Programa Nacional de Suplementação de Vitamina A. Brasília: Ministério da Saúde; 2013. Available from: http://bvsms.saude. gov.br/bvs/publicacoes/manual_condutas_suplementacao_ vitamina_a.pdf

17. Brasil. Ministério da Saúde. Portaria $n^{\circ} 1.498$, de 19 de julho de 2013. Redefine o Calendário Nacional de Vacinação, o Calendário Nacional de Vacinação dos Povos Indígenas e as Campanhas Nacionais de Vacinação, no âmbito do Programa Nacional de Imunizações (PNI), em todo o território nacional. Diário Oficial da União 2013; $1^{\text {a }}$ seção - p.31; 22 jul. Available from: http://bvsms. saude.gov.br/bvs/saudelegis/gm/2013/prt1498_19_07_2013.html

18. Pimentel FC, Albuquerque PC, Souza WV. A Estratégia Saúde da Família no estado de Pernambuco: avaliação da estrutura das equipes por porte populacional. Saúde Debate 2015;39(104):88-101.

19. Pedraza DF, Menezes TN, Costa GMC. Ações de alimentação e nutrição na estratégia saúde da família: estrutura e processo de trabalho. Rev Enferm UERJ 2016;24(4):e15848.

20. Junqueira TS, Cotta RMM. Matriz de ações de alimentação e nutrição na Atenção Básica de Saúde: referencial para a formação do nutricionista no contexto da educação por competências. Cienc Saude Colet 2014;19(5):1459-74.

21. Costa GD, Cotta RMM, Reis JR, Ferreira MLSM, Reis RS, Franceschini SCC. Avaliação da atenção à saúde da criança no contexto da Saúde da Família no município de Teixeiras, Minas Gerais (MG, Brasil). Cienc Saude Colet 2011;16(7):3229-40.

22. Monteiro FPM, Araújo TL, Ximenes LB, Vieira NFC. Ações de promoção da saúde realizadas por enfermeiros na avaliação do crescimento e desenvolvimento infantil. Cienc Enferm 2014;XX(1):97-110.

23. Almeida AC, Mendes LC, Sad IR, Ramos EG, Fonseca VM, Peixoto MVM. Uso de instrumento de acompanhamento do crescimento e desenvolvimento da criança no Brasil - Revisão sistemática de literatura. Rev Paul Pediatr 2016;16(1):7-19.

24. Silva SA, Baitelo TC, Fracolli LA. Avaliação da Atenção Primária à Saúde: a visão de usuários e profissionais sobre a Estratégia de Saúde da Família. Rev Latino-Am Enfermagem 2015;23(5):979-87.

25. Mesquita Filho M, Luz BSR, Araújo CS. A Atenção Primária à Saúde e seus atributos: a situação das crianças menores de dois anos segundo suas cuidadoras. Cienc Saude Colet 2014;19(7):2033-46.
26. Oliveira VBCA, Veríssimo MLOR. Assistência à saúde da criança segundo suas famílias: comparação entre modelos de Atenção Primária. Rev Esc Enferm USP 2015; 49(1):30-6.

27. Araújo RL, Mendonça AVM, Sousa MF. Percepção dos usuários e profissionais de saúde no Distrito Federal: os atributos da atenção primária. Saúde Debate 2015; 39(105):387-99.

28. Morici MC, Barbosa ACQ. A Gestão de Recursos Humanos em hospitais do Sistema Único de Saúde (SUS) e sua relação ao modelo de assistência: um estudo em hospitais de Belo Horizonte, Minas Gerais. Rev Adm Pública 2013;47(1):205-25.

29. Moimaz SAS, Marques JAM, Saliba O, Garbin CAS, Zina LG, Saliba NA. Satisfação e percepção do usuário do SUS sobre o serviço público de saúde. Physis 2010;20(4):1419-40.

30. Silva KD, Araújo MG, Sales LKO, Valença CN, Morais FRR, Morais IF. Acompanhamento do crescimento e desenvolvimento infantil na visão de mães da estratégia saúde da família. Rev Bras Pesq Saúde 2014;16(2):67-75.

31. Souza MB, Rocha PM, Sá AB, Uchoa SAC. Trabalho em equipe na atenção primária: a experiência de Portugal. Rev Panam Salud Publica 2013;33(3):190-5. 